\title{
New dental elements of the oldest proviverrine mammal from the Early Eocene of Southern France support possible African origin of the subfamily
}

Floréal Solé, Thierry Smith, Rodolphe Tabuce, and Bernard Marandat

Acta Palaeontologica Polonica 60 (3), 2015: 527-538 doi:http://dx.doi.org/10.4202/app.00146.2014

Here we describe and illustrate specimens of hyaenodont mammals from two early Eocene localities of Southern France: Fournes (Minervois) and Fordones (Corbières). Some of these specimens were previously described as cf. Hyracolestes sp. (Cimolesta, Sarcodontidae), a taxon only known from Asia, but new arguments allow their referring to the small proviverrine hyaenodont Parvagula palulae which was previously only recorded in Palette (Provence). The material notably includes the oldest $\mathrm{p} 4$ ever recorded for the European endemic subfamily Proviverrinae. This new material shows that, by the beginning of the early Eocene, proviverrines already displayed their typical combination of dental features characterized by the presence of a large paraconid and entoconid on $\mathrm{p} 4$. The comparison between the earliest European proviverrines and sinopines (a mostly North American radiation) supports the divergence of the two subfamilies by this time. Moreover, the early proviverrines are morphologically similar to the African hyaenodont Tinerhodon (late Paleocene). Consequently, the history of the European proviverrines is likely rooted in Africa. Finally, the new specimens support a similar age for the localities of Palette and Fordones, and a younger age for Fournes. Due to the ages of these localities Parvagula palulae must be regarded as the oldest proviverrine.

Key words: Hyaenodonta, Proviverrinae, Eocene, Europe, France, Fournes, Fordones.

Floréal Solé [floreal.sole@ naturalsciences.be] and Thierry Smith [thierry.smith@ naturalsciences.be ], D.O. Earth and history of Life, Royal Belgian Institute of Natural

Sciences, Rue Vautier 29, B-1000 Brussels, Belgium. Rodolphe

Tabuce [rodolphe.tabuce@univ-montp2.fr] and Bernard Marandat [bernard.marandat@univ-montp2.fr], Institut des Sciences de l'Évolution (UM2, CNRS, IRD), cc64, Université Montpellier 2, Place Eugène Bataillon, F-34095 Montpellier Cedex 05, France. 
This is an open-access article distributed under the terms of the Creative Commons

Attribution License (for details please see creativecommons.org), which permits unrestricted use, distribution, and reproduction in any medium, provided the original author and source are credited.

Faril text $(821.5 \mathrm{kB})$ 